\title{
Perception of The Teaching of Pathological Anatomy by Students of The Faculty of Health Sciences of the University of Lomé, Togo
}

Tchin Darré ( $\square$ paolodarre@yahoo.fr)

University of Lomé

\section{Toukilnan Djiwa}

University of Lomé

Ama Adjonko

University of Lomé

Luc Valère Codjo Brun

Université de Parakou

Nguiessan Aman

Université Alassane Ouattara

Panakinao Simgban

University of Lomé

Mohamed Kouyate

Université Félix Houphouët-Boigny

Gado Napo-Koura

University of Lomé

\section{Research Article}

Keywords: Pathological Anatomy, perception, teaching, Students, University of Lomé

Posted Date: December 30th, 2020

DOI: https://doi.org/10.21203/rs.3.rs-133293/v1

License: (c) (1) This work is licensed under a Creative Commons Attribution 4.0 International License. Read Full License 


\section{Abstract}

Background: The aim of this study was to assess the perception of the students of the Faculty of Health Sciences of the University of Lomé on the teaching of Pathological Anatomy.

Methods: This is an opinion survey carried out in 4 months at the University of Lomé among students of the faculty of health sciences (3rd in 8th year) on the perception of the teaching of Anatomy Pathological. The questionnaire was structured into 5 sections (socio-demographic, course organization, learning process, hospital internships, and general assessment)

Results: A total, 395 students responded to the questionnaire. Their mean age was $24.04 \pm 2.85$ years and the sex ratio (M/F) was 2.4. They were mostly in 7th year of medicine (155). Regarding the course organization, $58.5 \%$ of the participants felt that the course objectives were often achieved and $51.6 \%$ said the course was well structured. For $49.9 \%$, the important notions of the course were often sufficiently developed, and $55.2 \%$ affirm that the hourly volume was sufficient for the comprehension of the course. A statistically significant link was observed between the years of study and certain parameters of the learning process, namely: the adequacy between the theoretical course and the internships ( $p \otimes 0.0001)$, the understanding of the course by the learning process ( $\mathrm{p} \otimes 0.0001$ ), the essential documentation for the understanding of the course ( $\mathrm{p} 10.0001)$, the understanding of histological lesions through practical work ( $\mathrm{x} \otimes 0.0001$ ). Concerning the general satisfaction of the course, they were $50.4 \%$ to be satisfied and $57.8 \%$ to wish a better organization of the courses and practical work. There is a statistically significant relationship between the degree of satisfaction with teaching and grade ( $\mathrm{p} \otimes 0.037)$.

Conclusion: The teaching of pathological anatomy in its current form does not seem to provide the sufficient foundations and prerequisites desired by the students. It makes sense to strengthen their training through better organization of hospital internships and practical work, within the framework of the quality of teaching at the University of Lomé.

\section{Background}

Pathological Anatomy is a fundamental medical discipline that studies lesions caused by disease using techniques based on macroscopic and microscopic morphology [1]. A distinction is made between general pathological anatomy which studies the major lesional processes concerning the fundamental elements of an organism and special pathological anatomy which studies the pathologies of all the apparatuses of the human body [2]. Pathological anatomy provides care missions in the development of diagnosis, teaching and research [1]. The teaching mission pursues several objectives, in particular to acquire a level of knowledge which will allow the student to understand the challenges of this specialty [3]. Little is known about pathological anatomy, both in medical studies and in the general population [3, 4]. Few studies have been done on the teaching of pathological anatomy in order to meet the challenge of its ignorance. Indeed, the studies by Chatelain et al. (France), Holck et al. (Denmark) on the perception of the teaching of pathological anatomy by medical students found that $89 \%$ and $96 \%$ of students, 
respectively, considered their knowledge of pathological anatomy insufficient [4, 5]. In Togo, at the Faculty of Health Sciences of the University of Lomé, the teaching of pathological anatomy is limited during the first cycle of medical studies in the 3rd year. In sub-Saharan Africa, no teaching has been done on pathological anatomy. It is necessary to conduct studies among health personnel in general and medical students in particular to identify the problems inherent in the lack of knowledge of pathological anatomy in order to propose axes for better visibility of the discipline.. The objective of this study was to assess the perception of students of the Faculty of Health Sciences of the University of Lomé on the teaching of Pathological Anatomy and the factors that influence it.

\section{Methods}

This is an opinion survey conducted over 4 months (March-June 2020) at the Faculty of Health Sciences of the University of Lomé. Grades 3 to 8 medical students from the FSS were included in the study. We chose the students in 3rd, 4th; 5th, 6th, 7th and 8th year because in Togo, theoretical courses in pathological anatomy are taught in the 3rd year of medicine. And medical students are then scheduled for placements in Anatomy Pathology and other labs on a random basis. However, students can do internships on a voluntary basis in the various departments of their choice during the holidays. We included students who completed at least half of the hourly volume devoted to the teaching of pathological anatomy, in 3rd year of medicine. In fact, the teaching of pathological anatomy is provided in the 3 rd year at the Faculty of Health Sciences, and the total hourly volume is 360 hours, including theoretical, practical and supervised lessons. This teaching is provided by three teachers of magistral rank. An anonymous questionnaire form was sent to them by hand or by post to complete. An explanatory note on the survey was attached to the questionnaire. Participation in the survey was voluntary and anonymous. The questionnaire was organized into 5 sections (socio-demographic, course organization, learning process, hospital internships, general assessment). The agreement of the FSS authorities was obtained as well as the informed consent of the students. The statistical tests used are Pearson's chi-square test for qualitative variables and Student's test for quantitative variables. The significance threshold was set at $5 \%$.

\section{Results}

A total of 395 students responded to the questionnaire. The average age of the students was $24.04 \pm$ 2.85 years (18-36 years) and the sex ratio (M/F) was 2.4. Depending on the level of study of the participants, they were mostly in 7th year (155) and 5th year (80). Regarding the course organization, $58.5 \%$ of the participants felt that the course objectives were often achieved and $51.6 \%$ said the course was well structured. According to $50.6 \%$ of participants, the course objectives were often achieved at the end of each course. For $49.9 \%$, the important notions of the course were often sufficiently developed, and $55.2 \%$ affirm that the hourly volume was sufficient for the comprehension of the course. A link was observed between the years of study and certain parameters of the learning process, namely the adequacy between the theoretical course and the internships ( $\mathrm{p} \otimes 0.0001)$, the understanding of the course by the process of learning ( $\mathrm{p} \otimes 0.0001)$, the essential documentation for the understanding of the course 
( $\mathrm{p} \otimes 0.0001$ ), the understanding of histological lesions by public works ( $\mathrm{p} \otimes 0.0001$ ) (Table 1 ). Regarding the presentation of the course and interactions, $78.5 \%$ of participants felt that the information received during the first contact with the teacher made it possible to make a good start for the rest of the course. They were $55.2 \%$ to say that the teacher presents the subject in a clear and structured way. According to $43.3 \%$ of them, the teacher makes sure that the important concepts are well understood. In $42.5 \%$ and $36.7 \%$ of cases respectively, the participants said that the teacher was always or often available to answer questions. There was a relationship between years of study and information received at first contact ( $\mathrm{p} \otimes 0.0001$ ), availability of the teacher to answer questions ( $\mathrm{p} \otimes 0.0001)$ (Table 2). For hospital internships, $89.4 \%$ of respondents did not complete internships in the Pathological Anatomy Laboratory. Of those who did, $83.3 \%$ felt that this practicum was useful in training a doctor. There was a relationship between years of study and the effectiveness of the laboratory internship ( $p \otimes 0.0001)$. Regarding the general satisfaction of the course, they were $50.4 \%$ to be satisfied followed by those who are not very satisfied in $37.2 \%$. They were $57.8 \%$ to wish a better organization of internships and practical work. There was a relationship between degree of satisfaction with teaching and grade ( $\mathrm{p} \otimes 0.037)$ (Table 3 ). 
Table 1

Student perceptions of the course organization

\begin{tabular}{|c|c|c|c|c|c|c|c|c|}
\hline & $\begin{array}{l}\text { 3rd } \\
\text { year }\end{array}$ & $\begin{array}{l}\text { 4th } \\
\text { year }\end{array}$ & $\begin{array}{l}5 \text { th } \\
\text { year }\end{array}$ & $\begin{array}{l}\text { 6th } \\
\text { year }\end{array}$ & $\begin{array}{l}\text { 7th } \\
\text { year }\end{array}$ & $\begin{array}{l}\text { 8th } \\
\text { year }\end{array}$ & Total & p-value \\
\hline $\begin{array}{l}\text { Adequacy between theoretical } \\
\text { courses and internship }\end{array}$ & & & & & & & & $\$ 0.0001$ \\
\hline Yes & 11 & 14 & 38 & 31 & 100 & 14 & 208 & \\
\hline No & 25 & 27 & 42 & 30 & 55 & 8 & 187 & \\
\hline \multicolumn{8}{|c|}{ Learning approach promotes understanding of course content } & $凶 0.0001$ \\
\hline No & 14 & 19 & 26 & 18 & 16 & 0 & 93 & \\
\hline Yes & 22 & 20 & 40 & 21 & 31 & 5 & 139 & \\
\hline No information & 0 & 2 & 14 & 22 & 108 & 17 & 163 & \\
\hline \multicolumn{8}{|c|}{ Essential documentation for understanding the courses } & 0.02 \\
\hline Never & 0 & 1 & 2 & 0 & 6 & 0 & 9 & \\
\hline Sometimes & 6 & 5 & 14 & 13 & 49 & 7 & 94 & \\
\hline Often & 14 & 14 & 43 & 27 & 57 & 11 & 166 & \\
\hline Still & 16 & 21 & 21 & 21 & 43 & 4 & 126 & \\
\hline \multicolumn{8}{|c|}{ Location of availability of documentation } & 0.58 \\
\hline Online & 21 & 28 & 47 & 42 & 117 & 18 & 273 & \\
\hline Faculty Library & 6 & 9 & 19 & 16 & 33 & 4 & 87 & \\
\hline Not available & 7 & 8 & 16 & 11 & 19 & 2 & 63 & \\
\hline University of Lomé Library & 4 & 5 & 11 & 6 & 14 & 2 & 42 & \\
\hline CHU SO Library & 1 & 2 & 3 & 3 & 11 & 1 & 21 & \\
\hline Don't know & 1 & 1 & 3 & 2 & 3 & 2 & 12 & \\
\hline Handout & 0 & 2 & 2 & 0 & 0 & 0 & 4 & \\
\hline Among seniors & 0 & 0 & 1 & 0 & 1 & 0 & 2 & \\
\hline ESSAL Library & 1 & 0 & 0 & 0 & 0 & 0 & 1 & \\
\hline \multicolumn{8}{|c|}{ TP allow the understanding of histological lesions } & $\$ 0.0001$ \\
\hline Yes & 25 & 20 & 54 & 43 & 108 & 15 & 265 & \\
\hline No & 11 & 21 & 26 & 18 & 47 & 7 & 130 & \\
\hline
\end{tabular}


Table 2

Student perception of interactions and presentation of the course according to the years of study

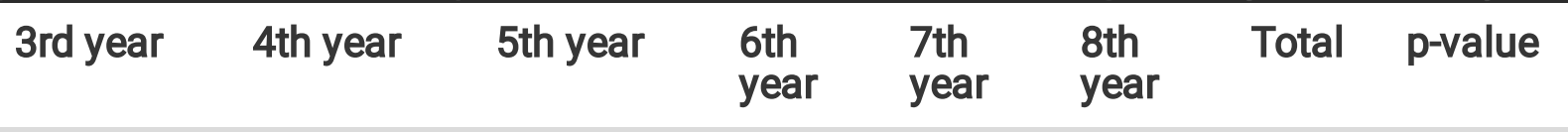

At first contact, the information I received allowed me to get off to a

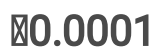
good start

$\begin{array}{llllllll}\text { Yes } & 25 & 29 & 63 & 43 & 132 & 18 & 310 \\ \text { No } & 11 & 12 & 17 & 18 & 23 & 4 & 85\end{array}$

Teacher presents the subject matter in a clear and structured manner

\begin{tabular}{llllllll} 
Sometimes & 2 & 4 & 8 & 5 & 19 & 4 & 42 \\
\hline Often & 19 & 26 & 52 & 34 & 76 & 11 & 218 \\
\hline Still & 15 & 11 & 20 & 22 & 60 & 7 & 135
\end{tabular}

The teacher ensures that the concepts are well assimilated

$\begin{array}{llllllll}\text { Never } & 0 & 0 & 2 & 0 & 1 & 0 & 3 \\ \text { Sometimes } & 9 & 13 & 22 & 19 & 46 & 8 & 117 \\ \text { Often } & 18 & 22 & 38 & 25 & 58 & 10 & 171 \\ \text { Still } & 9 & 6 & 18 & 17 & 50 & 4 & 104\end{array}$

Teacher shows interest in your understanding of the course

$\begin{array}{llllllll}\text { Never } & 0 & 0 & 0 & 0 & 2 & 0 & 2 \\ \text { Sometimes } & 4 & 11 & 17 & 10 & 33 & 6 & 81 \\ \text { Often } & 14 & 15 & 35 & 28 & 54 & 9 & 155 \\ \text { Still } & 18 & 15 & 28 & 23 & 66 & 7 & 157\end{array}$

Teacher available enough to answer your questions

0.051

\begin{tabular}{llllllll} 
Never & 0 & 1 & 0 & 0 & 3 & 0 & 4 \\
\hline Sometimes & 3 & 9 & 11 & 7 & 38 & 10 & 78 \\
\hline Often & 13 & 15 & 33 & 28 & 51 & 5 & 145 \\
Still & 20 & 16 & 36 & 26 & 63 & 7 & 168
\end{tabular}


Table 3

Degree of student satisfaction by year of study

\begin{tabular}{|llllll|}
\hline & Dissatisfied & Somewhat & Satisfied & Very Satisfied & Total \\
\hline 3rd year & 4 & 14 & 12 & 6 & 36 \\
\hline 4rd year & 2 & 21 & 16 & 2 & 41 \\
\hline 5rd year & 5 & 34 & 40 & 1 & 80 \\
\hline 6rd year & 1 & 22 & 36 & 2 & 61 \\
\hline 7rd year & 5 & 51 & 82 & 17 & 155 \\
\hline 8rd year & 0 & 5 & 13 & 4 & 22 \\
\hline Total & 17 & 147 & 199 & 32 & 395 \\
\hline
\end{tabular}

\section{Discussion}

The main limitation of our study is the sincerity of the information provided by the respondents. The participation rate was relatively low (47.0\%), significantly lower than those of studies from developed countries which were 58.0\%, 65.0\% and 73.0\% respectively in France, Denmark and the USA [4-6]. Indeed, our study took place in the context of the Corona Virus Disease (Covid-19) pandemic, with the discontinuation of classes, dramatically reducing student accessibility to the university campus. This also underlines the lack of student interest in this discipline in our regions. A male predominance was noted with a sex ratio (M / F) of 2.4. This could be explained by the low level of education of the young girl as well as the little interest of the latter for scientific disciplines in most of the developing countries $[7 ; 8]$. The majority of students $(89.4 \%)$ had not completed internships in the Anatomy Pathology laboratory. Of those who did, $83.3 \%$ felt that this internship is useful in training a doctor with a relationship between years of study and the effectiveness of the lab internship ( $\mathrm{p} \otimes 0.0001)$. The same observation was made in France [9]. The organization of the internship for medical students not allowing everyone to do internships in the LAP may explain the lack of knowledge of this specialty. A relatively acceptable proportion (50.4\%) of the participants had general satisfaction with the teaching of Pathological Anatomy, with a relationship between the degree of satisfaction with the teaching and the year of study ( $\mathrm{p} \otimes 0.037)$. This level of satisfaction is comparable to that of studies in developed countries $[5,10,11]$. One of the major problems with Pathological Anatomy remains its lack of visibility and its ignorance by students. A better knowledge of this probably lies in the development of educational interventions, the reception of students in the laboratory and the organization of Postgraduate Education $[12,13]$. The future of this specialty also requires better communication and better occupation in the field, with greater visibility of pathologists in the staff, multidisciplinary consultation meetings $[14,15]$. However, these interventions require great availability and a substantial number of pathologists, which is not yet the case in our country. 


\section{Conclusion}

Teaching general pathological anatomy helps students understand the pathophysiology of lesions. The study revealed the good presentation of the course and good interaction between teachers and students. However, the theoretical teaching of Pathological Anatomy does not seem to fully satisfy the students; with insufficient hours for the course to be understood. It therefore appears advisable to further strengthen student training by organizing internships and postgraduate courses with a view to better knowledge of the discipline.

\section{Declarations}

\section{Ethics approval and consent to participate}

This study was approved by the medical school of University of Lomé. We obtained also the agreement of participants after the explanation. The survey was anonymous and confidential. This study was approved by the "Comité de Bioéthique pour la Recherche en Santé (CBRS)" (Bioethics Committee for Health Research) from the Togo Ministry of Health, Ref N0: 0101/2016/MS/CAB/DGS/DPLET/CBRS). The study has been carried out in accordance with relevant guidelines and regulations.

\section{Consent for publication}

Not applicable.

\section{Availability of data and materials}

The datasets used and/or analyzed during the current study available from the corresponding author on reasonable request

\section{Competing interest}

The authors declare no conflicts of interest with regard to this article.

\section{Funding}

None

\section{Acknowledgements}

Not applicable

\section{Authors Contributions}

All authors substantially contributed to the present study. TD was responsible for the conception of the study, participated in the study design, performed the laboratory analysis and interpretation, and wrote the paper. TDj, AA, LVCB, NAA, PS, and MK were involved in the treatment and follow up of the patient; 
they have reviewed the paper. GNK was responsible for the overall scientific management of the study and the preparation of the final paper. All the authors have read and approved the final paper to be submitted for publication.

\section{References}

1. Guiyun Zhang, Bruce A. Fenderson, J. Jon Veloski, Michael Livesey, Tracey Wojdon-Smith. Medical School Anatomy and Pathology Workshops for High School Students Enhance Learning and Provide Inspiration for Careers in Medicine. Acad Pathol. 2016; 3: 2374289516685323. doi:

$10.1177 / 2374289516685323$

2. Just PA, Verkarre V, Mansuet-Lupo A, Rabant M, Daniliuc C, Radenen B, et al. Innovations in medical undergraduate pathology education: The Paris Descartes medicine faculty experience. Ann Pathol 2016;36(4):252-7.

3. Smith RD, Richard RW. A survey of first-year pathology residents: Factors in career choice. Hum Pathol 1987;18:1089-96.

4. Chatelain D, Charfi S, Cordonnier C, Leclercq F, Sevestre H. Medical students and the teaching of pathology: results of a survey in the faculty of medicine of Amiens. Ann Pathol 2009;29(3):173-9.

5. Holck S, Junge J, Hansen U, Holck PP, Norgaard T. Medical students' perceptions of pathology. Hum Pathol. 2007;38:384-5.

6. Holland L, Bosch B. Medical students' perceptions of pathology and the effect of the second-year pathology course. Hum Pathol. 2006;37(1):1-8

7. Teclessou JN, Saka B, Akakpo SA, Mouhari-Toure A, Panawè K, Kombate K, Pitche P. Perception of Dermatology by Medical Students in the Faculty of Health Sciences, University of Lomé (Togo). Our Dermatol Online. 2019; 10:138-41.

8. Matrane A, Serhier Z, Bennani Othmani M. Les critères de choix de la spécialité des médecins résidents de la faculté de médecine et de pharmacie de Marrakech (Maroc). Ped Med. 2012;13:17181.

9. Sonia Gaucher S, Thabut D. L'enseignement et l'enseignant influencent le choix de la spécialité médicale. Enquête auprès de 207 étudiants. Presse Med. 2013;42:e89-e95.

10. Mena G, Llupià A, Sequera VG, Aldea M. [Specialized health education: medical students' preferences and perceptions]. Med Clin (Barc). 2013;140(3):135-8.

11. McCloskey CB, Johnson K, Brissette M, Conran R, Childs J, George M, et al. Factors Influencing US Allopathic Medical Students to Choose Pathology as a Specialty. Acad Pathol. 2020;7:2374289520951924.

12. Pehlivanoglu B, Hassoy H, Calle C, Dendooven A, Nalbantoglu I, Reshchikova L, et al. How does it feel to be a pathology resident? Results of a survey on experiences and job satisfaction during pathology residency. Virchows Arch. 2017;471(3):413-422. 
13. Al Nemer A. Undergraduate medical students' perception of pathology. Ann Diagn Pathol. 2020;44:151422.

14. Magid MS, Shah DT, Cambor CL, Conran RM, Lin AY, Peerschke ElB, et al, Consensus Guidelines for Practical Competencies in Anatomic Pathology and Laboratory Medicine for the Undifferentiated Graduating Medical Student. Acad Pathol. 2015;2(4):2374289515605336.

15. Park YA, Marques MB. Teaching medical students basic principles of laboratory medicine. Clin Lab Med. 2007;27(2):411-24 